Notre Dame Law School

NDLScholarship

Journal Articles

Publications

2004

\title{
On the Historical School of Jurisprudence
}

Robert E. Rodes

Notre Dame Law School, robert.e.rodes.1@nd.edu

Follow this and additional works at: https://scholarship.law.nd.edu/law_faculty_scholarship

Part of the Jurisprudence Commons, and the Legal History Commons

\section{Recommended Citation}

Robert E. Rodes, On the Historical School of Jurisprudence, 49 Am. J. Juris. 165 (2004).

Available at: https://scholarship.law.nd.edu/law_faculty_scholarship/858

This Article is brought to you for free and open access by the Publications at NDLScholarship. It has been accepted for inclusion in Journal Articles by an authorized administrator of NDLScholarship. For more information, please contact lawdr@nd.edu. 


\title{
ON THE HISTORICAL SCHOOL OF JURISPRUDENCE
}

\author{
ROBERT E. RODES, JR.
}

Among schools of jurisprudence, the Historical School is like a poor and slightly eccentric relation. Everyone is polite to it, and no one explicitly disowns it, but no one really takes it seriously. Some writers mention its contribution to historical scholarship or its role in building up the intellectual life of nineteenth century German universities. Others have found it a forerunner of sociological jurisprudence on the one hand and Nazism on the other. Sir Carleton Kemp Allen, in his classical Law in the Making, says of Friedrich Karl von Savigny (1779-1861), the founder of the school:

If Savigny was an evolutionist before the evolutionists, so he was a sociologist before the sociologists. Without disrespect to their scholarly genius, it is difficult not to feel that unconsciously (for they could hardly guess what would be built on the foundations which they laid) Savigny and his followers were National Socialists before the National Socialists. ${ }^{1}$

But what Savigny and his followers really were was a school of jurisprudence - a way of looking at the enterprise of making and applying law. As is the case with other schools, we can learn things about jurisprudence from considering carefully what they have to say, even if we cannot follow them all the way.

The basic tenet of the school is that law in its essence is not something imposed on a community from above or from without, but is an inherent part of its ongoing life, an emanation of the spirit of the people. Savigny, in the little book that is taken as the foundation document of the school, puts the matter this way:

In the earliest times to which authentic history extends, the law will be found to have already attained a fixed character, peculiar to the people, like their language, manners, and constitution. Nay, these phenomena have no separate existence, they are but the particular faculties and tendencies of an individual people, inseparably united in nature, and only wearing the semblance of distinct attributes to our view. That which binds them into one whole is the common conviction of the people, the kindred consciousness of an inward necessity, excluding all notion of an accidental and arbitrary origin. ${ }^{2}$

1. Carleton Kemp Allen, Law in the Making, 6th ed. (Oxford: Clarendon, 1958), 86.

2. Frederick Charles von Savigny, Of the Vocation of our Age for Legislation and Jurisprudence, tr. Abraham Hayward (London, Littlewood, 1831; repr. Birminghom, Legal Classics Library, 986), 24. The translation is from the 1828 German edition. The first edition appeared in 1814 . 
In later works, Savigny was to use the term Volksgeist, spirit of the people, to designate what he regarded as the source of law. ${ }^{3}$ The German word is more evocative than the translation, so commentators have tended to leave it in place, and I shall do the same.

Savigny was aware of course that law, however it arose, could be subjected to scholarly analysis-he himself produced a good deal-and to legislative improvement. But scholars and legislators were not expected to create anew. Their task was to organize and clarify something that already existed, to make fuzzy distinctions sharp and vague boundaries precise. Occasionally, to be sure, new situations or new moral insights call for entirely new legislative enactments. But " $[t]$ hat enactments of this kind easily become a baneful corruption of the law, and that they should be most sparingly employed, must strike anyone who consults history." 4

When Savigny began his work, Germany was just beginning the process of recovering from the trauma of the French Revolution and the Napoleonic wars and achieving political unity. ${ }^{5} \mathrm{He}$ was immediately successful in persuading German legal scholars to abandon their precipitate embrace of the Code Napoleon, and to explore the medieval and Roman roots of their own law. He also provided one of the strands in the German romanticism that many, including Allen, quoted above, see as providing a sentimental backdrop for Hitler and his minions.

I am not persuaded, as Allen seems to be, that Savigny and his school made a significant contribution to the later Sociological School of jurisprudence. The two schools have in common that they rely more on empirical observation and less on philosophical speculation than some of the more rationalistic schools do. But there the common element ceases. One school adapts historical method to the law where the other adapts sociological method. There is some overlap between the two, but not a lot. It is sometimes possible for a historian to crunch numbers, and it is sometimes possible for a sociologist to

3. Friedrich Karl von Savigny, System des heutigen Römischen Rechts, vol. 1 (Berlin, Viet, 1840), 14. It appears that the term was first used in law by Puchta in 1828 . Georg Friedrich Puchta, Das Gewohnheitsrecht, Erster Teil (Barmstadt:Wissenschaftliche Buchgesellschaft, 1965)(1828), 138. Before that, it had been used in philosophy by Hegel. G. W. F. Hegel, Vorlesungen über die Philosophie der Weltgeschichte, ed. K.H. Ilting et al. (Berlin: Felix Meiner Verlag, 1996) (1822-23), 318. For the earlier development of the concept, see Nathan Rotenstreich, "Volksgeist," 4 Dictionary of the History of Ideas, 490 at 491-3 (New York: Scribner, 1974).

4. Savigny, supra, note 2,32 .

5. Hermann Kantorowicz, "Savigny and the Historical School of Jurisprudence," 53 Law Quarterly Review 326 (1937). 
make an empathetic leap where there are no numbers to crunch. More often, though, the two disciplines go their separate methodological ways.

Sociological jurisprudence is also unique in the dominance within the school of technological metaphors, led by Roscoe Pound's central metaphor of "social engineering." This school studies for the sake of control, and its central problem is that history is subject to no such control as it proposes. The Historical School proposes rather to make incremental improvements on the basis of an understanding of the ongoing historical process of which we are a part:

[T] he subserviency of the present to the past will manifest itself even when the present is purposely opposed to the past. There is consequently no mode of avoiding this overruling influence of the existing matter; it will be injurious to us as long as we ignorantly submit to it; but beneficial if we oppose to it a vivid creative energy - obtain the mastery over it by a thorough grounding in history, and thus appropriate to ourselves the whole intellectual wealth of preceding generations.

Of course, the Volksgeist carries a mystique that is not reducible to learning by experience. Through it law is traced back to a people's sense of its identity and of its own particular ways of doing things. It is the extravagant sweep that Savigny claims for this mystique that has brought forth the most telling criticisms to which his Historical School has been subjected by practical-minded English and American jurists. Here is how John Chipman Gray states the most obvious objection:

By the law of Massachusetts, a contract by letter is not complete until the answer of acceptance is received. By the law of New York, it is complete when the answer is mailed. Is the common consciousness of the people of Massachusetts different on this point from that of the people of New York? ... In truth, not one in a hundred of the people in either state has the slightest notion on the matter. ${ }^{8}$

Savigny meets this objection by claiming that judges and legal scholars work out the technical details on behalf of the people. ${ }^{9}$ Gray points out that the sophistication and eclecticism of legal scholars make this argument untenable:

6. Roscoe Pound, Social Control Through Law (New Haven, Conn.: Yale University Press, 1942), 64.

7. Savigny, supra, note $2,132-33$.

8. John Chipman Gray, The Nature and Sources of the Law (New York: MacMillan, 1927), 90-91.

9. Savigny, supra, note 3,45 and translated in Gray, supra, note 8,91. 
It might be very desirable that the conceptions of the Volksgeist should be those of the most skillful of the community, but however desirable this might be, it is not the case. The Volksgeist carries a piece of sulphur in its waistcoat pocket to keep off rheumatism, and thinks that butchers cannot sit on juries. ${ }^{10}$

Furthermore, a lot of twentieth century jurisprudence shows how some law aims at actually changing public attitudes and what Karl Llewellyn calls "folkways" by deploying incentives and disincentives. ${ }^{11} \mathrm{I}$ believe that public attitudes toward both race segregation and abortion have been changed in this way during my own time.

Finally, it has been pointed out that in Egypt in 1883, Japan in 1898, and Turkey in 1926, longstanding legal traditions were thrown overboard and replaced by Civil Codes imported almost verbatim from Europe. ${ }^{12}$ There is no indication that these foreign codes do not serve the ongoing life of the peoples of these countries at least as well as the traditional legal systems that grew out of their historical consciousness. In fact, they probably serve the ongoing lives of their women a good deal better.

India also imported its legal system from the West. It appropriated the English common law system, with suitable Indian material introduced not by the people of India or their juristic surrogates, but by English lawyers, most notably Macaulay. ${ }^{13}$ M.C. Setalvad, the Attorney General of India, lecturing on the subject at Lincoln's Inn in 1960, concludes:

For over a hundred years, distinguished jurists and judges in India have, basing themselves upon theories of English common law and statutes, evolved doctrines of their own suited to the peculiar need and environment of India. So has been built up on the basis of the principles of English law the fabric of modern Indian law which notwithstanding its foreign roots and origin is unmistakably Indian in its outlook and operation. ${ }^{14}$

He quotes with approval a writing by Holdsworth analogizing the process to the reception of Roman law in medieval Europe. ${ }^{15}$ That reception introduced into Savigny's thought a paradox that many commentators have noticed. The

10. Gray, supra, note 8,92 .

11. Karl Llewellyn, "Law Observance Versus law Enforcement," 1928 Proceedings of the Conference of Social Work 127 (1928).

12. F. P. Walter, "The Historical School of Jurisprudence and Transplantations of Law," 9 Journal of Comparative Law, 3d Series (1928) 183.

13. Thomas Babington Macaulay, "Government of India" in Speeches on Politics and Literature 95, 121 (London: Everyman's Library, 1909). The speech was delivered in the House of Commons on July 10, 1833.

14. M.C. Setalvad, The Common Law in India (London: Stevens, 1960), 225.

15. Ibid., 224-25. 
German Volksgeist seems to be pretty solidly grounded on Justinian's Institutes. ${ }^{16}$ Setalvad's tracing of the development of common law in India may suggest that Savigny is less paradoxical than he seems. The adoption of a new legal system can be an authentic historical development like any other. It can be part of the historical evolution of a people whether it comes from within or from without, and whether it comes suddenly or gradually. If the Japanese, for instance, are not less themselves for playing baseball and making cars, they are probably not less themselves for copying parts of the German Civil Code.

It is possible to present the tenets of the Historical School in a straightforward practical form. Law is part of the culture of society. Different peoples have different laws just as they have different styles of clothing and different favorite foods. Legal enactments can nudge the culture in one direction or another, but if the culture rejects them firmly enough they will fail of their purpose: hence, for instance, the long hiatus between Brown v. Board of Education and the final desegregation of Southern schools. ${ }^{17}$ Economic and social developments affect both what law is needed and what law is possible: consider the effect of women's liberation on alimony. Historical experience affects moral judgment and with it the willingness to accept this or that form of legal restraint: German free speech doctrine is a good deal less tolerant of racist talk than our own is. ${ }^{18}$

All this is true, but I do not think it reaches the real significance of the Volksgeist. Savigny set up his doctrine as a challenge to two theories that were commonly accepted in his day. They are still commonly accepted, and they still need to be challenged. One is an understanding of law as command: "According to this theory, all law in its concrete form, is founded upon the express enactments of the supreme power. Jurisprudence has only the contents of the enactments for its object."19 The other is a one-size-fits-all understanding of natural law: "The conviction that there is a practical law of nature or reason, an ideal legislation for all times and all circumstances, which we have only to discover to bring positive law to permanent perfection. ${ }^{20}$ Against both, the Historical School insists that the laws of a particular people emerge,

16. F.W. Maitland, "Translator's Introduction" in Otto Gierke, Political Theories of the Middle Age, tr. F. W. Maitland (Cambridge: Cambridge University Press, 1900), xv-xvi.

17. Constance Baker Motley, "Twenty Years Later," The Continuing Challenge(Evanston, Ill., Integrated Educ. Assoc., 1975) 11.

18. E. Stein, "History Against Free Speech: The New German Law Against the 'Auschwitz' and other 'Lies"' 85 Michigan Law Review 277, 278 (1987): "The experience with the abuse of freedoms that contributed to the demise of the Weimar Republic and the suppression of these freedoms by the National Socialist regime left a deep imprint upon the Basic Law and subsequent legislation."

19. Savigny, supra, note 2, 22-3.

20. Ibid., 23. 
and ought to emerge, from the unique historical experience of that people. It emerges also, if we are to take the Volksgeist seriously, from unique spiritual qualities of that people-qualities originally formed, no doubt, by their historical experience, but freestanding at any given point of time.

As philosophy of history, these claims of the Historical School run counter to the Enlightenment project of liberating individual creativity from the weight of inherited restraint. As historiography, they reject the "Whig" interpretation of history as a story of irresistible progress. ${ }^{21}$ As metaphysics, they bring into question any generic view of the human condition or of human character. I will consider the historical aspect first, and then turn to the metaphysical.

Among the famous aphorisms of Justice Holmes is one that "historic continuity with the past is not a duty, it is only a necessity."22 It was a necessity of which Enlightenment thinkers were not much aware. Their enterprises were continually attempting to do away with inherited institutions and values, and build anew from scientific principles. In France, they started a new numbering of years, they renamed all the months, and they decimalized the weeks. ${ }^{23}$ In America, they argued that a majority of the voters could adopt a new constitution whenever they pleased. ${ }^{24}$ In England, they developed philosophies of government with mathematical precision and tried to get them enacted into law. ${ }^{25}$ Not all of their efforts were successful, but during the period between the French Revolution and the First World War, their ways of looking at the world came to dominate Western thought.

Historical writing in the period reflected that dominance. It tended to presuppose an ideal consummation in which Enlightenment values would prevail everywhere, and to treat a given series of historical events as either happily furthering or unhappily hindering the coming to pass of that consummation. Herbert Butterfield characterized this tendency as "The Whig Interpretation of History," ${ }^{26}$ naming it after the party that British historians regarded as attempting with some success to impose an Enlightenment agenda on their country. There were a few dissenters from the approach, notably the Marxists, but they too envisaged a consummation of history in terms of which particular historical events could be evaluated.

21. Herbert Butterfield, The Whig Interpretation of History (London: Bell, 1931).

22. Oliver Wendell Holmes, "Learning and Science," Collected Legal Papers (New York: Harcourt Brace, 1920), 138-39.

23. "Revolutionary Calendar," Encyclopedia Americana 23 (1986) 455. The metric system was a more enduring result of the same impulse. See "Measures and Measuring Systems," Encyclopedia Americana 18 (1986) 584.

24. See Luther v. Borden, 48 U.S. 1 (1849).

25. Elie Halévy, England in 1815, tr. Watkin and Barker (1961), 572-77.

26. Butterfield, supra, note 21. 
On the Enlightenment view, the subjection of law to history made it part of the problem rather than part of the solution. The codifiers of the nineteenth century tended to assign to law goals and values independent of history-what I have called the one-size-fits-all version of natural law. Jurists of the first half of the twentieth century tended rather to see law as taking control of history. Roscoe Pound's use of technological metaphors such as "social engineering"27 was a notable example. Either approach is belied by Herbert Butterfield's stern historiography, which insists that the effects of a particular intervention in the historical process can be neither predicted nor controlled. ${ }^{28}$

Paradoxically, it is the recognition of the Volksgeist that emancipates law from dependence on history. Enlightenment values, although they purport to be historically neutral, are in fact the values of a particular time and place. As long as we ignore their historical contingency, we will not be able to give them whatever place they deserve in the development of our law. Now, at the beginning of the twenty-first century, the difficulty seems particularly acute. The historian Johannes Huizinga, in his book The Waning of the Middle Ages, suggests that there is value in looking in history at the ends of periods:

History has always been far more engrossed by problems of origins than by those of decline and fall. ... But in history, as in nature, birth and death are equally balanced. The decay of overripe forms of civilization is as suggestive a spectacle as the growth of new ones. And it occasionally happens that a period in which one had, hitherto, been mainly looking for the coming to birth of new things, suddenly reveals itself as an epoch of fading and decay. ${ }^{29}$

Huizinga's view, which he supports effectively by examples, is that when a certain set of ideas and attitudes has dominated society long enough, it gets run into the ground. All its potentialities are realized, and the attempt to develop them further leads to absurdity and frustration, and finally to a settled melancholy until new ideas and attitudes take over with new possibilities to

\section{Pound, supra, note 6 .}

28. See Butterfield, supra, note 21, 19:

"It is nothing less than the whole of the past, with its complexity of movement, its entanglement of issues, and its intricate interactions, which produced the whole of the complex present; and this, which is itself an assumption and not a conclusion of historical study, is the only safe piece of causation that a historian can put his hand upon, the only thing which he can positively assert about the relationship between past and present. When the need arises to sort and disentangle from the present one fact or feature that is required to be traced back into history, the historian is faced with more unravelling than a mind can do, and finds the network of interactions so intricate, that it is impossible to point to any one thing in the sixteenth century as the cause of any one thing in the twentieth."

29. J. Huizinga, The Waning of the Middle Ages (Garden City: Doubleday, 1954), 5. 
be realized and new challenges to be met. It is hard for a person reading the United States Supreme Court Reports, opening any half dozen recent academic publications, or even watching television not to believe that this is what has happened in our day to the ideas and attitudes of the Enlightenment. Individual creativity, freed from inherited restraints, has gone from the Declaration of Independence, the steam engine, the novel, and antibiotics to Auschwitz, nuclear weapons, topless dancing, and crack cocaine.

The grassroots are not immune to the rise and fall of attitudes and ideas in history, but they are less receptive to sudden radical change than either intellectuals or power wielders are. Adherence to a Volksgeist, therefore, can curb the enthusiasm of legislators for putting new ideas into practice simply because they have the power to do so. Long before Savigny drew on the concept to check the adoption of the Code Napoleon in Germany, English lawyers were drawing on their ancient and idiosyncratic legal system to check the absolute monarchy that was the first legal embodiment of Enlightenment thought. As Roscoe Pound put it in The Spirit of the Common Law:

In the seventeenth century, it was progressive to insist upon the royal prerogative. Those who thought of the king as the guardian of social interests and wished to give him arbitrary power, that he might use it benevolently in the general interest, were enraged to see the sovereign tied down by antiquated legal bonds discovered by lawyers in such musty and dusty parchments as Magna Carta. ${ }^{30}$

Long after Savigny, by the same token, we find Mary Ann Glendon seeking to "tap the reserves of wisdom, virtue, and imagination that Americans still display in their varied communities of memory and mutual aid"31 for the purpose of "refining the rhetoric of rights" in response to the hypertrophied individualism that she finds dominating our national appropriation of Enlightenment thought. ${ }^{32}$ It is easy to see her argument as an appeal to the American Volksgeist to correct the excesses of academic absolutism that have grown up in our law.

The tenets of the Historical School provide a useful rhetoric for anyone who wants to set up a customary way of doing things against the powers of arbitrary benevolence or mindless rationality. But it will not do to embrace a doctrine for its rhetorical convenience if it is in fact not true. So we must turn at this point to metaphysical and moral questions. Is there a Volksgeist? If so,

30. Roscoe Pound, The Spirit of the Common Law (Boston: Marshall, Jones, 1921), 63.

31. Mary Ann Glendon, Rights Talk (New York: Free Press, 1991), xiii.

32. Ibid., 171-83. 
is there any particular value in conforming to it? And if there is such a value, how does it relate to more universal values, such as human solidarity?

It is clear to me that the answer to the first question is yes. There is a Volksgeist, which people come by through having a common history and a common narrative account of it. It is to this that Martin Luther King appeals when he claims support in "the sacred heritage of our nation,"33 and this is what he has in mind when he claims to be part of "a movement designed to save the soul of a nation." " Its development is treated in a perceptive book, Race Pride and the American Identity, by the sociologist Joseph Rhea. Rhea shows how "a new American collective consciousness" 35 has been produced by a restatement of our history to do more justice to the minorities who were on the losing end of our various historical struggles. This common consciousness, the historical experience that gives rise to it, and the common ways of doing things that go with it add up, I believe, to a metaphysical reality that can properly be called a Volksgeist.

French schoolchildren are taught that to be a nation is to have done great things together and to wish to do more. ${ }^{36}$ This is the positive aspect of a common history. There may be a negative aspect also. People may have done bad things together, or bad things to each other, and wish not to do any more of them. In either case, we become situated in time and space by recognizing a particular history as our own. My colleague Teresa Phelps has written of the work of Truth and Reconciliation Commissions in allowing the victims of unspeakable oppression to tell their stories and thereby play their part in the construction of a master narrative under which oppressors and oppressed can live together. ${ }^{37}$ In the same way, Rhea, in the book just referred to, shows how American minorities have claimed a place in the common life of our country by giving its master narrative a new and less triumphalist form. The process is the flip side of the construction of patriotic songs and folklore that goes into the shared memory of a people. For good or ill, both sides of the process are part of the moral and spiritual baggage of anyone who is born into the people

33. Martin Luther King, Letter from the Birmingham Jail (Philadelphia: American Friends Service Committee, 1963), 13.

34. "Man of the Year," Time, January 3, 1964, 13, 27.

35. Joseph Tilden Rhea, Race Pride and the American Identity (Cambridge, Mass.: Harvard University Press, 1997), 7.

36. Bernard Lescot and Jean Sinou, Instruction Civique, 29th ed. (Paris: Editions Andr, 1983), 40. "La Nation, comme l'individu, est l'aboutissement d'un long passé d'efforts, de sacrifices et de dévouements. Avoir fait de grandes choses ensemble, vouloir en faire encore, voilá a les conditions essentielles pour être un peuple." Ibid. The authors attribute the quotation to Renan.

37. Teresa Godwin Phelps, Shattered Voices (Philadelphia: University of Pennsylvania Press, 2004). 
in question, or who wishes to join them. Recent immigrants into the United States and their children have sometimes tried to disclaim responsibility for slavery and its aftermath, pointing out that neither they nor their ancestors were involved in it. But their disclaimer cannot be accepted. Anyone who becomes an American becomes an inheritor of the American past.

The metaphysical recognition of a people goes with a similar recognition of other continuing bodies. Alumni speak of a college spirit, students of corporation law speak of a corporate culture. People attach spiritual qualities to cities, and no one gainsays them. Here too, a newcomer to the corporate body is expected to appropriate the corporate ethos and the corporate past as his own. One of the most moving monuments I know is in the chapel of New College, Oxford, surrounded by medieval, seventeenth century, Georgian, and Victorian memorabilia of all kinds. It says:

In memory of the men of this college who coming from a foreign land entered into the inheritance of this place $\&$ returning fought $\&$ died for their country in the war 1914-1918

followed by three German names. Where there is a shared history, a shared heritage, there is a metaphysical reality.

While New College, Oxford is a metaphysical reality distinct from, say, the London School of Economics, both are part of the metaphysical reality of the United Kingdom. Similarly, I believe that the United Kingdom, France, Brazil, Zimbabwe, and all the other nations of the world are part of a metaphysical reality of humankind. Just as there is a Volksgeist for a particular people developed out of its particular history, so there is a worldwide Volksgeist, a Volksgeist of the human race, developed out of the history of the world. For this reason, the Historical School of jurisprudence, while it is inconsistent with what I have called one-size-fits-all natural law, is not inconsistent with natural law as such. Human nature sets limits to the legal styles of different peoples just as the shape of the human body sets limits to their clothing styles. For obvious reasons, a particular people would be no more apt to come up with a law to permit driveby shootings than to come up with a fashion for six-legged trousers or shoes without soles.

Writers in the natural law tradition have also seen legal institutions common to every system of which they are aware, but not, in their opinion, philosophically required by human nature. These they have included in what they call jus gentium, the law of peoples. ${ }^{38}$ If we can attribute the laws of a particular people to a particular Volksgeist, we should be able to attribute the

38. See Paul Vinogradoff, "Historical Types of International Law," Collected Papers of Paul Vinogradoff, Vol. 2, ed. H. A. L. Fisher, 248 at 269-72 (Oxford: Clarendon, 1928); Thomas Aquinas, Summa Theologica, Pts. II, II, 57, 3. 
jus gentium to the Volksgeist of humanity. The most important of the institutions traditionally attributed to the jus gentium is private property. In point of philosophy or theology, all the resources of the world are common to all the people of the world. But long historical experience has led to the conclusion that some form of private property is required to distribute the common resources for people to use. ${ }^{39}$

The worldwide Volksgeist, and therefore the provisions of the jus gentium, develop through time, whereas human nature, and therefore the requirements of natural law, do not. Jacques Maritain, in his book On the Philosophy of History describes what he calls a "law of the world significance of history making events" 40 and a "law of prise de conscience." when a major historical transition such as the French Revolution takes place anywhere, its effects are felt worldwide. According to the second, people's perception of right and wrong develops with historical experience. Putting the two together, we can see documents like the Universal Declaration of Human Rights and principles like the criminal liability of rulers who violate those rights gradually working their way into the jus gentium or what is called "customary international law."42

Theologians have discerned a comparable development in the moral teaching of the Catholic Church. Continuing reflection on the original deposit of revelation, plus people's experience of trying to love their neighbors through the continuing vicissitudes of history have continually led to new understandings of how Christians should live:

39. See Drostan Maclaren, Private Property and the Natural Law (Oxford: Blackfriars, 1942), 14-23.

40. Jacques Maritain, On the Philosophy of History (New York: Scribner, 1957), 62.

41. Ibid., 69. Maritain goes on to take up "the progress of the moral conscience" as a related law. Ibid., 104-07.

42. Maritain, who played a major part in the development of the Universal Declaration of Human Rights, saw it as a product of a practical consensus between those who accept and those who reject natural law as the basis of human rights. For the second group, "man's rights are relative to the historical development of society." "Introduction" in UNESCO, Human Rights: Comments and Interpretations (Westport, Conn.: Greenwood Press, 1949) 9, 13-4. At the same time, the proponents of natural law could concede that "although certain fundamental rights meet a prime necessity of that law, while others meet only a secondary necessity or are merely desirable, nevertheless our knowledge of both is in all circumstances subject to slow and irregular growth, so that those rights only stand forth as acknowledged rules of conduct as moral consciousness progresses and societies evolve." Ibid. I think Maritain's analysis justifies me in seeing the Declaration as entering into the jus gentium through a development of the worldwide Volksgeist. On the status of the Declaration and the rights embodied in it as international law, see Filartiga v. Pena-Irala, 630 F.2d 876 (2d Cir. 1980). 
With the help of the Holy Spirit [the Volksgeist of the Church], it is the task of the entire People of God, especially pastors and theologians, to hear and interpret the many voices of our age, and to judge them in the light of the divine Word. In this way, revealed truth can always be more deeply penetrated, better understood, and set forth to greater advantage. ${ }^{43}$

This passage is from the Second Vatican Council's Gaudium et Spes. It is immediately preceded by an exhortation to preach the Gospel to different peoples in accordance with their different ways of thinking, "For thus each nation develops the ability to express Christ's message in its own way." 44

Even in the Church, the divine prerogative of direct intervention in the process of historical development is only sparingly exercised. The Volksgeist as we actually encounter it among the subjects of any given legal system is apt to display a daunting mixture of good things and bad. In our own case, we cannot deny the justice of the 1960 s black activist's remark that "violence is as American as cherry pie," ${ }^{, 45}$ or of Kipling's evocation of the American Spirit in such lines as "His hands are black with blood; his heart/ Leaps as a babe's at little things." 46 We might note also that the most prominent of the legal institutions that arose spontaneously among us in rather the manner Savigny had in mind was slavery. ${ }^{47}$ The Volksgeist, taken by itself, cannot provide an adequate criterion for distinguishing good laws from bad.

Well, then, what good is it? Suppose we accept that the Volksgeist exists, and is, as Savigny claimed, a primary source of a people's law. The fact may be of profound significance for history, for anthropology, even for philosophy. But what does it mean for jurisprudence? I believe the place to look for an answer is in the trends that Savigny sought to oppose in developing his theory-the idea that law is nothing but an exercise of power by the person or persons in authority, and the one-size-fits-all understanding of natural law. Against these, the Historical School has insisted that if an exercise of power is not to be either tyrannous or ineffective, it must take account of the history

43. Gaudium et Spes, no. 44 in The Documents of Vatican II, ed. Walter M. Abbott, S.J. (New York: American Press, 1966) 246.

44. Ibid.

45. H. Rap Brown, Oxford Dictionary of Modern Quotations (Oxford: Oxford University Press), 41.

46. Rudyard Kipling, “An American,” Rudyard Kipling's Verse: Inclusive Edition, 1885 1918 (Garden City, N.Y.: Doubleday, 1926), 210.

47. I have not found in any of the literature any reference to an articulated decision that the institution of slavery should exist in the British possessions in North America or the Caribbean. It appears that the first blacks in the colonies were on the same level as indentured servants, but that they were soon distinguished from whites by making their servitude perpetual. See, e.g., Paul Finkelman, The Law of Freedom and Bondage: A Casebook (New York: Oceana, 1986), $1-25$. 
and predilections of the people it is to affect, and that one size does not fit all, because historical experience affects the way human nature is instantiated in a particular people.

Corollary to these doctrines, and most important in a revolutionary age, is the principle that as far as possible law reform should be brought about by repairing existing dispositions rather than by demolishing them and setting up new ones. Edmund Burke makes this point eloquently in his Reflections on the Revolution in France, a work that evidently influenced Savigny:

By a constitutional policy working after the pattern of Nature, we receive, we hold, we transmit our government and our privileges in the same manner in which we enjoy and transmit our property and our lives. The institutions of policy, the goods of fortune, the gifts of Providence, are handed down to us, and from us, in the same course and order.... Thus, by preserving the method of Nature in the conduct of the state, in what we improve we are never wholly new, in what we retain we are never wholly obsolete. ${ }^{48}$

Note how effectively Burke appeals at once to a general Nature and a particular history. In contrast, he tells his French correspondent:

[Y]ou chose to act as if you had never been moulded into civil society, and had everything to begin anew. You began ill, because you began by despising everything that belonged to you. You set up your trade without a capital.... Respecting your forefathers, you would have been taught to respect yourselves. You would not have chosen to consider the French as a people of yesterday, as a nation of low-born, servile wretches until the emancipating year of $1789 .{ }^{49}$

He argues that, while France had fallen lately into despotism, it had in its own traditions sufficient material for the restoration of freedom: "You might have repaired those walls; you might have built on those old foundations." 50

When we turn the doctrines we have been looking at into working jurisprudence, we come up with four principles that can have considerable utility in the task of making and applying law.

First, there is the principle that one size does not fit all. This principle is somewhat against the American grain, so we have to work at applying it. One example is in the making of constitutions. We have a custom of doing that by convention and referendum. ${ }^{51}$ That is, when we want a new constitution

48. Edmund Burke, Reflections on the Revolution in France, ed. J.G.A. Pocock (Buffalo, New York: Prometheus, 1987) (1790), 29-30.

49. Ibid., 31-32.

50. Ibid., 31.

51. Albert 1. Sturm, Methods of State Constitutional Reform (Ann Arbor, Mich.: University of Michigan Press, 1954) 25-8. See also, "Constitutional Law," 16 C.J.S. $\$ 8$ (1984); and "Constitutional Law," 16 Am. Jur. 2d § 23 (1998). 
- which, given our fifty states, we do fairly often-we elect a convention to draft one. When they have drafted it, we submit it to a referendum of the people it is to serve. If they adopt it by a majority vote, we happily put it in force, and regard the government chosen under it as the only legitimate government for the people in question. The process works every time. But when we tried it in Vietnam in 1967, it did not work at all. We (or the Vietnamese at our instigation) got up a convention, a referendum, and an election just as we do at home, ${ }^{52}$ but it gave the leaders no more legitimacy in the eyes of their people than they had had before. We have also made a few gestures toward doing the same thing in Afghanistan. We unearthed from the local traditions something that looked a little like a convention, laid hold of it with all our might, and tried to elicit from it a government that the whole country would accept. ${ }^{53}$ The returns are not all in yet, but they are not promising. We have made somewhat similar moves in Iraq, with equally dubious results. It is commendable to replace anarchy, terror, and corruption with stable democratic government, but we cannot do it without looking carefully at the history and culture-in a word, the Volksgeist-of the people affected.

The debate over racial preferences- "affirmative action"-often involves a choice between one-size-fits-all and a more historically nuanced approach. It is possible to say that all distinctions based on race are inherently unacceptable, but if you say that, you will have to condemn the recognition by African countries of different marriage and inheritance customs for different tribes, the exemption of Indians from certain hunting and fishing regulations, and the reservation of certain lands in Hawaii for descendants of the original inhabitants ${ }^{54}$ right along with segregated schools for American blacks. The underlying principle of natural law is that all human beings are of equal worth. But how the worth of a particular group of people is to be affirmed today depends in great part on how it was denied some other day. To judge particular principles of American law in this regard without considering the history of race relations in our country is to come up with nonsense.

Sometimes requirements peculiar to a given legal system are imposed by the evolved structure of the system itself. Thus, in Duncan $v$. Louisiana

52. Richard Nixon, "United States Foreign Policy for the 1970's - Building for Peace," Weekly Comp. Pres. Doc. 7 (March 1, 1971) 305.

53. Human Rights Watch, "Q. and A. on Afghanistan's Loya Jirga Process," http://www.hrw.org, (last accessed September 14, 2004).

54. See Rice v. Cayetano, 528 U.S. 495 (2000) (striking down racial limitation on right to vote for trustees of property held in trust for native Hawaiians). In my opinion, the case was wrongly decided. 
(1968), ${ }^{55}$ the United States Supreme Court held that an American criminal proceeding could not be fair if the accused did not have the opportunity to be tried before a jury. Not that any system to be fair must permit a jury trial, but that ours must:

A criminal process which was fair and equitable but used no juries is easy to imagine. It would make use of alternative guarantees and protections which would serve the purposes that the jury serves in the English and American systems. Yet no American State has undertaken to construct such a system.... In every State, including Louisiana, the structure and style of the criminal process - the supporting framework and the subsidiary procedures-are of the sort that naturally complement jury trial, and have developed in connection with and in reliance upon jury trial. ${ }^{56}$

Louisiana evidently did not try to draw on the French and Spanish roots of its legal system to justify the limitations it imposed on the right to a jury. In its criminal proceedings, it had used the jury from the outset in the same way as other states. ${ }^{57}$

The second principle of working jurisprudence that comes out of the thinking of the Historical School is that it is better to repair than to build anew. This is the gist of Burke's reproach to his correspondent in France. The revolutionaries of 1789 have not been the only ones to disregard it. Most of us come from time to time upon a convoluted situation in which the best thing to do seems to be to throw out the baby with the bathwater and find a new baby. But the solidly successful legal innovations have always been those founded on a careful appropriation of experience. Our Federal Rules of Civil Procedure, for instance, make good use of experience both under the earlier procedural codes and under the common law. Almost every rule can be traced back to a common law predecessor, and explained in terms of what was wrong with the earlier forms. This is equally true of other codifications such as the Uniform Commercial Code and the Federal Rules of Evidence. Indeed, the Code Napoleon itself owes its success more to its adherence to past practices than to its departure from them. ${ }^{58}$

Savigny's most cogent objection to codification was that it interferes with the continuing appropriation of experience:

55. 391 U.S. 145 (1968).

56. Ibid.,149-50n.

57. Edward Livingston, A System of Penal Law for the State of Louisiana (Philadelphia: James Kay, 1833; repr. Birmingham, Ala.: Legal Classics Library, 1991), 10-14.

58. Savigny, supra, note 2,74 . 
For if . . circumstances should be favourable to a revision of the law, nothing would be more conducive to the end in view than the being extensively connected with preceding intelligent times; but the code now stands between, impeding and throwing difficulties in the way of this connection on all sides. ${ }^{59}$

I think the best codifications show that Savigny was too pessimistic here. ${ }^{60} \mathrm{I}$ have taught and studied the Federal Rules of Civil Procedure in terms of their historical antecedents, and I find in the modern rules a most useful lens through which to view the procedural wisdom of our ancestors. Take, for instance, Rule 2, "There shall be one form of action to be known as "civil action." This language, first adopted in the New York Code of Civil Procedure of $1848,{ }^{61}$ puts an end to centuries of frustration with cases thrown out of court for being brought under the wrong form of action. Taken together with the requirement that a pleading contain "a short and plain statement of the claim showing that the pleader is entitled to relief," 62 it is generally regarded as putting an end to the requirement imposed by some courts under the 1848 Code and its progeny that every plaintiff adopt a particular theory of recovery and plead accordingly. ${ }^{63}$ At the same time, an Appendix of Forms attached to the Rules makes it clear that a claim can be stated in terms of the theory it invokes if such a statement will contribute to clarity. Experience of trying to plead "the facts constituting the cause of action" under the 1848 Code and its progeny ${ }^{64}$ led to this approach.

The point is that these rules embody a great deal of experience of how best to state a claim. And they make that experience more accessible by eliminating the futile arguments and forensic disappointments that the old practice attached to minor errors or miscalculations in the process. In the same way, Rule 12(b)(6), providing for dismissing a complaint for "failure to state a claim on which relief can be granted," gives better access than the old demurrer practice did to the basic insight of our system that legal questions should be decided before the facts are tried.

59. Ibid., 40-41.

60. To be sure, what Savigny has in mind seems to be a codification of all the existing law, not just a particular part of it. Ibid., 33. But his objection would seem to apply as much and as little to the one case as to the other.

61. 1848 N.Y. Laws, c. $379, \S 62$.

62. Fed. R. Civ. P., Rule 8(a)(2).

63. See Charles E. Clark, Handbook of the Law of Code Pleading (St. Paul, Minn.: West Publishing Co., 1928), 47-51.

64. 1848 New York Laws, supra, note, 61, c. 379, § 119. See also, Clark, supra, note 63, 138-79. 
The Uniform Commercial Code also was built on a solid foundation of experience. ${ }^{65}$ The common law, the various Uniform Acts adopted during the first decades of the twentieth century, and current commercial practice were all taken into account. The object of the drafters was to streamline various procedures that had become unnecessarily cumbersome over time, to get rid of certain unfortunate interpretations of the existing law, and to secure uniformity among the different states. ${ }^{66}$ The goal of uniformity had a lot to do with the adoption in 1896 of a Civil Code for Savigny's own Germany. It too was built on existing foundations, and its proponents were not slow to point out that it was more in accord with the German spirit than the Code Napoleon would have been. ${ }^{67}$

In short, there are codes and codes. Savigny's strictures on the subject suggest caution, but in many cases the roots of legal material in the Volksgeist can be tapped better with a code than without. Either way, the old foundations should be built upon as far as possible rather than replaced.

The third principle is that official enactment is not always necessary to change the law. Law is meant to regulate the way people live together in society, and changes in the way they live together will inevitably be reflected in the law. The common law of England requires the owner of chickens to fence them in so they will not eat up a neighbor's grain. In 1913, the Supreme Court of Iowa refused to follow this rule:

The customs and habits of our people with reference to the care of poultry are so well established and so thoroughly understood that we think all would be shocked, to say the least, by a pronouncement from this court that they must fence them in. ${ }^{68}$

65. According to U.C.C. $\$ 1-102$, the purposes of the Code are "(a) to simplify, clarify, and modernize the law governing commercial transactions, (b) to permit the continued expansion of commercial practices through custom, usage and agreement of the parties [i.e., through continuing reference to the Volksgeist] and (c) to make uniform the law among the various jurisdictions." The intentions of the framers with regard to particular aspects of earlier law are set forth in Comments attached to particular provisions of the Code. See especially the Official Comment attached to §9-101. Uniform Laws Annotated 3A (West Group, 2002), 273. And note that $\S 1-103$ provides for using "the principles of law and equity including the law merchant" to supplement the Code when needed. (Ibid.) In this way, the Code expressly avoids abolishing its past in the manner envisaged by Savigny's objections.

66. Richard Danzig, "A Comment on the Jurisprudence of the Uniform Commercial Code," Stanford Law Review 27 (1975) 621.

67. See Michael John, Politics and Law in Late Nineteenth-Century Germany (Oxford: Clarendon, 1989) 244-45; and Maitland, supra, note 16, xvii.

68. Kimple v. Schafer, 1453 N.W. 505, 507 (Iowa 1913). 
But in 1977, when a motorist was injured trying to avoid a flock of geese in the road, the same court held the owner of the geese liable, pointing to the changes in road transport since 1913, and to the replacement of free ranging chickens by chickens raised in giant buildings: "The established "customs and habits of our people with reference to the care of poultry' have largely gone the way of the Model T Ford." ${ }^{\text {69 }}$

In 1982, abandoning a long string of precedents, the Court of Appeals of Indiana held that a married woman was liable for her own medical expenses: "The anachronistic issue raised by this appeal is analogous to the current status of the black bear in Indiana." $"$ The court pointed out that the non-liability of the wife dated back to a time when she did not have control of her own property, and should not have survived the adoption of statutes giving her such control. Changes in the customs and habits of our people regarding the marriage relationship have also resulted in one place or another in making a husband punishable for rape of his wife, ${ }^{71}$ abolishing the common law tort of alienation of affections, ${ }^{72}$ and requiring a wife to support her husband. ${ }^{73}$

My fourth principle is the converse of the third. It is that legal enactments do not necessarily change social practice. What I have in mind here is not the obvious fact that some people disobey the law, but the equally true although less obvious fact that there are some laws that almost everybody disobeys. Laws are generally adopted to curb social deviance and to resolve disputes in accordance with prevailing standards. When they set out to change prevailing standards and make conduct deviant that was formerly the norm, they are often frustrated. It is possible to make changes of this kind by the judicious deployment of legal incentives and disincentives, but Savigny is quite right to point out that no lawmaker can leave the current state of the Volksgeist out of account. I recently saw a 60 Minutes program on dowries in India. ${ }^{74}$ It seems that the families of grooms are demanding such extravagant dowries that brides' families can fall into penury trying to meet the demand. The situation is now so bad that large numbers of girl babies are being aborted, resulting in such a gender imbalance that many men cannot find anyone to marry. The

69. Weber v. Madison, 251 N.W.2d 523, 529 (lowa 1977).

70. Memorial Hospital v. Hahaj, 430 N.E.2d 413, 413 (Ind. Ct. App. 1982).

71. See, e.g., State v. Smith, 426 A.2d 38, 45 (N.J. 1981).

72. E.g., Wyman v. Wallace, 615 P.2d 452 (Wash. 1980).

73. See, e.g., Harry D. Krause, Family Law in a Nutshell (St. Paul, Minn.: West Publishing Co., 1995), 109. I have not found a case of a husband actually suing his wife for non-support, but the duty of support is generally regarded as following from Orr v. Orr, 440 U.S. 268 (1979) (state must give husband same right to alimony as wife) and Frontiero v. Richardson, 411 U.S. 577 (1973) (husband of female military officer must be given same benefits as wife of male officer).

74. CBS, 60 Minutes: For Love of Money (October 6, 2003). 
giving and receiving of dowry were prohibited by statute in $1961,{ }^{75}$ but the statute has not made much of a dent in the prevailing custom. Indeed, the actual murder of brides who fail to come up with sufficient dowry goes all too frequently unpunished. ${ }^{76}$

The nearest we have come in our own country to systematic disregard of the written law has been in the case of nationwide Prohibition and the case of racial equality in the Southern States. In both cases, the written law butted hard against entrenched folkways. In one, the folkways prevailed; in the other, they eventually succumbed. The difference is instructive. Prohibition incorporated a simplistic understanding of law as command. It resulted from the temporary superiority at the ballot box of people who thought that drinking was evil, and that they could make it go away by enacting laws against it. The values it embodied never commanded a consensus in the country, and no effort was made to bring one about. Threats and vilification were just about the only things that the proponents of the law used to get people to obey it. ${ }^{77}$ Civil rights legislation, by contrast, was adopted as part of a broad movement to change people's attitudes. The success of the legislation was inseparable from the success of the movement. ${ }^{78}$

$* * *$

What I call working jurisprudence has to provide answers to two questions: Why do we have some laws and not others? And how can I tell good laws from bad? These questions can be articulated in other ways, but one way or another, they need to express the twofold function of the enterpriseexplanation and critique. Competing theories, therefore, are not like competing philosophical theories, which all aim at a unitary truth. So if one philosopher says essence is prior to existence, and another says existence is prior to essence, we know that at least one of them is wrong. But when Holmes says law is a prediction of what judges will do in fact, ${ }^{79}$ and Hart says law is a system of primary and secondary rules ${ }^{80}$ they may both be right or at least partly right. So when I propose a new look at the Historical School of jurisprudence, I am not suggesting that it should displace any of the other

75. Dowry Prohibition Act, 1961 (India, Act No. 28 of 1961).

76. U.S. State Department, Country Reports of Human Rights Practices for 2001, (Washington, D.C.), 2439-40.

77. See William Gibbs McAdoo, The Challenge: Liquor and Lawlessness Versus Constitutional Government (New York: Century Co., 1928).

78. See, e.g., Michael J. Klarman, "Brown, Racial Change and the Civil Rights Movement," Virginia Law Review 80 (1994) 7, 137-38 (1994).

79. Oliver Wendell Holmes, "The Path of the Law," Harvard Law Review 10 (1987), 457, 461.

80. H.L.A. Hart, The Concept of Law (Oxford: Clarendon, 1961) 92-95. 
schools on the market. What I am suggesting is that it provides explanations and critiques in a number of cases where alternative schools fail to do so.

Take my 1977 lowa case of the person who was injured trying to avoid a flock of geese in a highway. If law is a system of primary and secondary rules, one would have to say that the earlier chicken case created a primary rule in Iowa that the owner of domestic fowl was not obliged to fence them in, and that no secondary rule could account for a change. And if law is a prediction of what the courts will do, one could not have predicted this case from studying law books. But, as I believe I have shown, the kind of analysis offered by the tenets of the Historical School makes it possible both to explain the 1977 holding, and to approve it. One can then go further and make of the explanation and approval a basis for predicting how cases will be decided in the future, and a basis for discerning a rule of recognition that will apply to certain new primary rules. In this way, we can develop a working harmony among the theories that might be applied to the case.

In short, there is good reason to give the doctrines of the Historical School a respected, although not an exclusive place, among the principles of jurisprudence. 